\title{
Klasterisasi Jenis Musik Menggunakan Kombinasi Algoritma Neural Network, K-Means dan Particle Swarm Optimization
}

\author{
Alhaji Sheku Sankoh', Ahmad Reza Musthafa², Muhammad Imron Rosadi ${ }^{3}$, Agus Zainal Arifin ${ }^{4}$ \\ Program Pasca Sarjana Teknik Informatika, Institut Teknologi Sepuluh Nopember \\ Kampus ITS Keputih, Sukolilo, Surabaya 60111, Jawa Timur \\ E-mail: ${ }^{1}$ alhajisheku82@hotmail.com, ${ }^{2}$ rezaaltraz@yahoo.com, ${ }^{3}$ imron_uyp@yahoo.com, ${ }^{4}$ agusza@cs.its.ac.id
}

Masuk: 16 Desember 2014; Direvisi: 16 Januari 2015; Diterima: 26 Januari 2015

\begin{abstract}
Having a number of audio files in a directory could result to unstructured arrangement of files. This will cause some difficulties for users in sorting a collection of audio files based on a particular category of music. In some previous studies, researchers used a method conducting to group documents on a web page. However, those studies were not carried out on file containing documents such as audio files; relatively they were conducted on files that contain text documents. In this study, we develop a method of grouping files using a combination of preprocessing approach, neural networks, k-means, and particle swarm optimization to obtain a form of audio file collections that are group based on the types of music. The result of this study is a system with improved method of grouping audio files based on the type of music. The pre-processing stage has therefore produced the best results on this approach based on spectrum analysis melody and bass guitar, which offers a value precision 95\%, 100\% recall and an F-Measure 97.44\%.
\end{abstract}

Keywords: Cluster, Music, NN, K-Means, PSO

\begin{abstract}
Abstrak. Banyaknya file audio pada suatu direktori membuat sususan file tidak terstruktur. Hal ini akan menyulitkan pengguna untuk mengurutkan bahkan memilah kumpulan file audio berdasarkan kategori tertentu, khususnya kategori berdasarkan jenis musik. Pada penelitian sebelumnya, dilakukan pengelompokan dokumen pada suatu halaman website. Namun hal tersebut tidak dilakukan pada file selain dokumen, seperti file audio. Penelitian ini bertujuan untuk mengembangkan metode pengelompokan file berupa kombinasi pendekatan preprocessing, neural network, k-means, dan particle swarm optimization dengan masukan berupa file audio sehingga diperoleh keluaran berupa kumpulan file audio yang telah terkelompok berdasarkan jenis musik. Hasil dari penelitian ini yaitu berupa suatu sistem dengan pengembangan metode dalam pengelompokan file audio berdasarkan jenis musik. Metode pada tahap pre-processing memiliki hasil terbaik pada pendekatan berdasarkan analisa spectrum melodi gitar dan bass, di mana memiliki nilai precission 95\%, recall 100\% dan F-Measure 97,44\%.

Kata kunci: Klaster, Musik, NN, K-Means, PSO
\end{abstract}

\section{Pendahuluan}

Secara umum sebagai salah satu bagian dari seni, musik merupakan suatu kumpulan bunyi atau nada dari suara vokal atau instrumen maupun gabungan keduanya yang disusun sehingga memilki ritme tertentu yang mampu menghasilkan keindahan dari segi bentuk, harmoni, dan mengandung ide atau nilai perasaan emosi tertentu. Tidak semua suara atau bunyi dapat dikategorikan sebagai musik. Contoh suara yang tidak dapat dikategorikan sebagai musik adalah suara klakson kendaraan di jalanan, suara gesekan daun pepohonan, suara desiran ombak, dan suara tidak beraturan lainnya (Oxford University Press, 2014). Perkembangan musik di jaman modern ini sangatlah pesat. Ada ribuan musik yang diciptakan setiap harinya oleh berbagai pencipta musik untuk memenuhi kebutuhan para penikmat musik. 
Efisiensi dan kecerdasan pencarian informasi musik menjadi topik yang sangat menarik sejak abad ke-21. Dua masalah fundamental dalam berurusan dengan data musik adalah klasifikasi dan klasterisasi (Li, dkk.2009: 477). Klasterisasi data musik adalah mengelompokkan data musik berekstensi MP3 berdasarkan karakteristik yang terkandung dalam data musik dengan tujuan untuk membagi berbagai data musik berdasarkan karakteristik yang serupa atau mirip. Pada saat ini klasifikasi musik menurut genre, seperti Alternative, Christian/Gospel, Country/Folk, Dance/Electronic, Eclectic, Indie, Jazz Blues, Pop, Rock, atau Word (Meyers, 2004: 16). Kalau di Indonesia jenis musik yang termasuk populer yaitu dangdut.

Penelitian klasterisasi data musik telah dilakukan oleh beberapa peneliti, misalnya penelitian yang dilakukan olehYang, dkk (2009: 876). Pada penelitian tersebut dilakukan klasterisasi data musik menggunakan metode $K$-means, spectral, dan affinity propagation. Dengan membandingkan ketiga metode tersebut, diperoleh nilai akurasi berturut-turut $83,2 \%$, $85,4 \%$, dan $82,1 \%$. Penelitian lain yang dilakukan dengan metode yang berbeda menggunakan metode KPSO, yaitu suatu algoritma optimasi evolusi baru hibrida didasarkan pada penggabungan $K$-means dan algoritma PSO. Melakukan uji coba dengan membandingkan metode $K$-means, PSO, PSOK, KPSO, KPSOK untuk klasterisasi dokumen web. Hasilnya kombinasi $K$-means dan PSO lebih unggul daripada $K$-means dan PSO secara individu (Jaganathan and Jaiganesh, 2013: 772).

Seleksi fitur merupakan sebuah tahapan penting dalam proses klasifikasi, karena fitur yang terseleksi sangat mempengaruhi tingkat akurasi dari klasifikasi. Pada dataset yang memiliki banyak fitur membutuhkan proses untuk mereduksi fitur sebanyak mungkin. (Saputra, 2011:1) mengusulkan sebuah metode seleksi fitur menggunakan Ensemble Random Forest dan Neural Network.

Berdasarkan hasil klasterisasi data menggunakan berbagai metode berbeda, maka pada penelitian ini peneliti melakukan klasterisasi data musik dengan jumlah klaster yang optimal menggunakan kombinasi algoritma Neural Network, K-means dan PSO. Diharapkan dengan penelitian ini, dapat mengklasterisasi berbagai macam musik dengan baik dan mendapatkan kelas-kelas yang tepat sesuai dengan fitur yang dimilikinya. Setelah terbagi menjadi beberapa kelas yang sesuai, akan ditetapkan labelisasi terhadap kelas tersebut. Dari hasil labelisasi ini, pengguna dapat mengetahui jenis musik yang terkandung dalam kelas-kelas musik yang telah terbagi.

\section{Pendekatan dan Tinjauan Pustaka \\ 2.1. Pemilihan File Audio}

Musik terdiri dari enam elemen yaitu modus, tempo, pitch (register), irama, harmoni dan melodi (Meyers, 2004: 24). Pada penelitian ini, dilakukan pengambilan fitur dengan memanfaatkan spektrum melodi gitar dan bass dari setiap file audio. Melodi gitar dan bass memiliki range frekuensi antara $80-1000 \mathrm{~Hz}$. Setiap file audio memiliki rata-rata durasi antara tiga sampai empat menit. Format audio yang digunakan pada penelitian ini yaitu berformat MP3 yang memiliki sampling rate $44100 \mathrm{~Hz}$. Dengan besarnya nilai sampling rate tersebut, maka dibutuhkan proses untuk menyederhanakan data menjadi fitur yang lebih spesifik. Hal tersebut dapat dilakukan pada tahap-tahap selanjutnya, yaitu pada tahap praproses dan ekstraksi fitur.

\subsection{Praproses Sinyal Audio}

Praproses sinyal suara digunakan untuk meningkatkan kualitas sinyal suara. Praproses sinyal suara merupakan langkah penting untuk membentuk sistem pengenalan suara atau identifikasi pembicara yang handal dan efisien. Langkah praproses yang digunakan pada penelitian ini yaitu preemphasis dan endpoint (Keerio, dkk., 2009: 216). Fungsi dari preemphasis sama dengan high-pass filter yaitu untuk menekan komponen frekuensi tinggi dari sinyal suara. Misalkan $s(n)$ adalah sinyal suara maka, preemphasis dapat dinyatakan dengan Persamaan 1, dimana $y(n)$ adalah sinyal preemphasis dan $\alpha$ adalah konstanta yang bernilai 0,94 . 
$y(n)=s(n)-\alpha \cdot s(n-1)$,

Deteksi endpoint digunakan untuk membedakan antara bagian speech dan nonspeech di sinyal suara. Deteksi endpoint yang digunakan pada penelitian ini berdasarkan short-time energy. Short-time energy menggambarkan kuantitas sinyal suara yang dinyatakan dengan kuadrat dari amplitudo. Short-time energy dinyatakan dengan Persamaan 2, dimana $E_{k}$ adalah energi pada frame ke- $k, N$ adalah jumlah sampel dalam satu frame, $w(m)$ adalah fungsi window, dan $x_{k}(m)$ adalah sinyal suara.

$E_{k}=\sum_{m=0}^{N-1} x_{k}^{2}(m)=\sum_{m=0}^{N-1}[w(m) x(k+m)]^{2}, \quad 0 \leq m \leq N-1$,

\subsection{Pemrosesan Sinyal Audio dan Ekstraksi Fitur}

Pemrosesan sinyal audio dan ekstraksi fitur digunakan untuk mengubah sinyal audio menjadi beberapa tipe representasi parametric, sehingga memudahkan pada proses selanjutnya. Hal ini sering dikaitkan dengan pengolahan sinyal. Ada banyak cara untuk merepresentasikan sinyal audio secara parametris sehingga dapat diproses lebih lanjut, antara lain dengan menggunakan Linier Predictive Coding, Mel Frequency Cepstrum Coefissients (MFCC) dan masih ada banyak lagi (Gupta, dkk., 2013: 102).

MFCC didasarkan pada variasi bandwith frekuensi dari telinga manusia, atau bagaimana manusia mendengar. Linear pada frekuensi rendah, dan logaritmik pada frekuensi tinggi. Teknik ini baik digunakan untuk menangkap karakteristik dari suara manusia. Hal ini diekspresikan dalam skala mel-frequency, yang linear pada frekuensi di bawah $1000 \mathrm{~Hz}$, dan logaritmik untuk frekuensi di atas $1000 \mathrm{~Hz}$. Gupta, dkk. (2013) melakukan ekstraksi fitur musik dengan langkah-langkah yang akan dijelaskan selanjutnya. Gambar 1 merupakan grafik masukan sinyal audio.

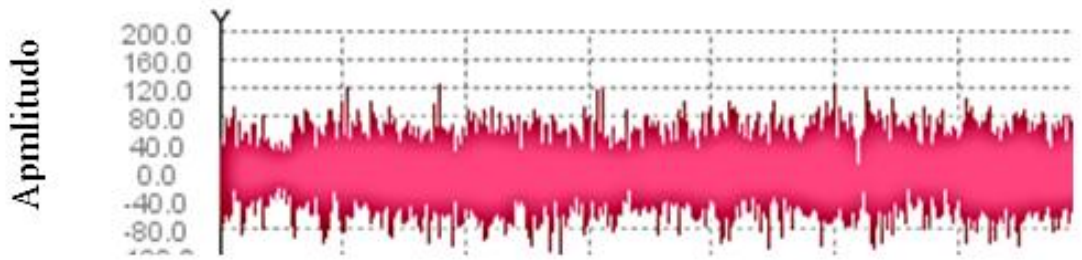

Waktu

\section{Gambar 1. Grafik Masukan Sinyal Audio (Sumber: Grafik aplikasi pada penelitian ini)}

Langkah 1: Frame Blocking. Sinyal suara dibagi menjadi blok-blok kecil yang disebut frame. Antara frame satu dengan yang lain terjadi tumpang tindih (overlapping). Tiap frame terdiri dari $N$ sampel dan tumpang tindih sebanyak $M$ sampel. Pada penelitian ini panjang frame yang digunakan adalah $\sim 30$ milidetik atau $N=256$ sampel. Sedangkan panjang tumpang tindih adalah $\sim 10$ milidetik atau $M=100$ sampel. Tujuan frame blocking adalah membagi sinyal suara menjadi frame kecil yang cukup sampel untuk mendapatkan cukup informasi. Jika ukuran frame terlalu kecil, informasi yang didapat tidak cukup untuk dipercaya. Sebaliknya jika terlalu besar, informasi di dalam frame sering berubah-ubah.

Langkah 2: Windowing. Proses windowing dilakukan untuk tiap frame. Windowing digunakan untuk meminimalkan ketidaksinambungan pada awal dan akhir frame. Dengan menggunakan window, sinyal suara pada awal dan akhir frame menjadi runcing. Hasil dari perhitungan windowing ditunjukkan pada Persamaan 3, dimana $w(m)$ adalah fungsi window dan $x(m)$ adalah sinyal suara. Pada penelitian ini fungsi window yang digunakan adalah hamming window yang dinyatakan dengan Persamaan 4. 
$y(m)=w(m) x(m), \quad 0 \leq m \leq N-1$,
$w(m)=0.54-0.46 * \cos \left(\frac{2 \pi m}{N-1}\right), \quad 0 \leq m \leq N-1$,

Langkah 3: Fast Fourier Transform (FFT). Fast Fourier Transform (FFT) merubah sinyal suara dari domain waktu ke domain frekuensi. FFT adalah algoritma tercepat yang mengimplementasikan Discete Fourier Transform (DFT). DFT dinyatakan dengan Persamaan 5, dimana $j$ adalah bilangan imajiner yang bernilai $\sqrt{-1}$ dan $x(m)$ adalah sinyal suara. Hasil dari proses ini disebut sebagai spektrum.

$X(k)=\sum_{m=0}^{N-1} x(m) e^{-j 2 \pi k m / N}, \quad k=0,1,2, \ldots, N-1$,

Langkah 4: Mel-frequency Filtering. Besaran frekuensi hasil FFT dipetakan menggunakan mel-scale yang dinyatakan dengan Persamaan 6, dimana $f$ adalah frekuensi maksimum. Mel frekuensi kemudian dibagi menjadi $L$ filter. Pada penelitian ini jumlah filter yang digunakan adalah 26 filter.

$\operatorname{mel}(f)=2595 * \log \left(1+\frac{f}{700}\right)$

Langkah 5: Discrete Cosine Transform (DCT). Setelah didapatkan spektrum mel, dilakukan operasi DCT. DCT selain untuk mengembalikan ke domain waktu juga untuk kompresi spektrum. Operasi DCT dapat dinyatakan dengan Persamaan 7 , dimana $L$ adalah jumlah mel spektrum filter, $D(m)$ adalah mel spektrum, dan $N$ adalah jumlah koefisien cepstrum. Pada penelitian ini jumlah koefisien cepstrum yang digunakan adalah 13 dan untuk komponen pertama, $C(0)$, tidak dipakai karena mengandung sedikit informasi. Jadi jumlah koefisien cepstrum yang akan dipakai adalah 12 cepstrum.

$C(k)=\sum_{m=1}^{L}(\log D(m)) \cos \left[\mathrm{k}\left(m-\frac{1}{2}\right) \frac{\pi}{L}\right], \quad k=0,1,2 \ldots, N-1$,

Langkah 6: Delta \& Delta-delta Cepstrum. Pendengaran manusia lebih sensitif terhadap karakteristik dinamik sinyal suara. Turunan pertama (delta) dan turunan kedua (deltadelta) menggambarkan karakteristik dinamik dari sinyal suara. Nilai delta cepstrum didapatkan dari turunan pertama koefisien cepstrum yang dinyatakan dengan Persamaan 8, dimana $C(\mathrm{k})$ adalah koefisien cepstrum dan $T$ bernilai konstan. Pada penelitian ini konstanta $T$ bernilai dua. Sedangkan delta-delta cepstrum didapatkan dari turunan pertama delta cepstrum.

$d(k)=\frac{\sum_{t=1}^{T} t(C(k+t)-C(k-t))}{2 \sum_{t=1}^{T} t^{2}}$,

Langkah 7: ZCR. ZCR: Sebuah zero-crossing dikatakan terjadi jika sampel berturutturut memiliki tanda-tanda yang berbeda. Zero-crossing Ratio adalah jumlah time-domain zerocrossings dan jumlah sampel dalam frame (Wang, dkk., 2011: 392). Zero-crossing Rate (ZCR) adalah fitur lain akustik dasar yang dapat dihitung dengan mudah. Ini adalah tingkat tanda perubahan sepanjang sinyal, tingkat dimana perubahan sinyal dari positif ke negatif dan kembali. Fitur ini telah digunakan di kedua pengenalan suara dan musik pencarian informasi (Wang, dkk., 2011). Pada Persamaan 9 ZCR adalah sinyal diskrit sampling, $\mathrm{N}$ berarti number poin sampling. 
$\mathrm{ZCR}=\frac{1}{2 N-1} \sum_{\mathrm{n}-1}^{\mathrm{N}-1} \operatorname{sgn}[\mathrm{x}(\mathrm{n}+1)-\operatorname{sgn}(\mathrm{n})]$

\subsection{Klasterisasi}

Klasterisasi adalah mengelompokkan obyek-obyek berdasarkan karakteristik yang dimilikinya. Tujuan klasterisasi adalah untuk membuat benda-benda dalam suatu kelompok menjadi serupa atau behubungan satu sama lain dan berbeda dengan benda-benda di kelompok lainnya. Klaster dapat mengklasifikasi obyek sehingga setiap obyek yang paling dekat kesamaannya dengan obyek lain berada dalam klaster yang sama.

Sebelum melakukan klasterisasi, peneliti melakukan pemilihan fitur terbaik dengan menggunakan algoritma NN. Setelah mendapatkan fitur terbaik dilakukan klasterisasi menggunakan algoritma $K$-means. Untuk mengoptimalkan hasil klaster pada data musik, peneliti menggunakan PSO.

\subsubsection{Neural Network}

Proses pemilihan fitur sangat mempengaruhi hasil dari proses klasterisasi. Metode yang digunakan untuk seleksi fitur pada penelitian ini adalah Neural Network. Neural Network merupakan sebuah mesin klasifikasi yang dimodelkan meniru dari struktur biologi pada saraf manusia. Pada penelitian ini neural network yang digunakan termasuk dalam jenis MLP (Multi Layer Perceptron) dimana terdapat hidden layer sebelum output dari perceptron di proses. MLP juga dikenal sebagai FFNN (Feed-Forward Neural Network). Secara umum model ini bekerja dengan menerima suatu vektor input $I$ dan kemudian menghitung suatu respon atau output $O$ dengan memproses (propagating) I melalui beberapa elemen-elemen proses yang saling terkait (Suhartono, 2007: 44).

Pada FFNN elemen-elemen proses tersusun dalam beberapa lapis (layer) dan data input mengalir dari satu lapis ke lapis berikutnya secara berurutan. Pada tiap lapisan input data ditransformasikan ke dalam lapis berikutnya secara nonlinear oleh elemen-elemen proses dan kemudian diproses ke lapis berikutnya. Akhirnya nilai output $O$ yang didapat berupa nilai scalar atau vektor, yang dihitung pada lapisan output (Suhartono, 2007: 45).

Untuk seleksi fitur Neural Network akan digunakan sebagai mesin klasifikasi yang kemudian akan di hitung selisih nilai error yang dihasilkan. Dapat dikatakan bahwa jika sebuah fitur ketika dihapus membuat nilai error semakin bertambah besar maka fitur tersebut merupakan fitur yang baik dan direkomendasikan untuk digunakan, dan sebaliknya (Suhartono, 2007: 45).

\subsubsection{K-means}

$K$-means merupakan salah satu metode clustering non hirarki yang berusaha mempartisi data yang ada ke dalam bentuk satu atau lebih cluster. Metode ini mempartisi data ke dalam cluster sehingga data yang memiliki karakteristik yang sama dikelompokkan ke dalam satu cluster yang sama dan data yang mempunyai karateristik yang berbeda di kelompokan ke dalam cluster yang lain. Secara umum algoritma dasar dari K-means Clustering adalah sebagai berikut.

Langkah 0: Tentukan jumlah cluster. Langkah 1: Alokasikan data ke dalam cluster secara random. Langkah 2: Hitung centroid/rata-rata dari data yang ada di masing-masing cluster. Untuk menghitung jarak antara centroid dengan data dapat menggunakan Euclidean Distance. Persamaan 10 adalah persamaan dari Euclidean Distance. Langkah 3: Alokasikan masing-masing data ke centroid/rata-rata terdekat. Langkah 4: Kembali ke langkah 2, apabila nilai centroid belum konvergen.

$$
d_{i j}=\sqrt{\sum_{k=1}^{p}\left\{x_{i k}-x_{j k}\right\}^{2}}
$$

dimana: $d_{i j}=$ Jarak objek antara objek $\mathrm{i}$ dan $\mathrm{j} ; \mathrm{P}=$ Dimensi data; $\mathrm{X}_{\mathrm{ik}}=$ Koordinat dari obyek $\mathrm{i}$ 
pada dimensi $\mathrm{k} ; \mathrm{X}_{\mathrm{jk}}=$ Koordinat dari obyek $\mathrm{j}$ pada dimensi $\mathrm{k}$.

\subsubsection{Particle Swarm Optimization}

Particle Swarm Optimization atau biasa disingkat PSO merupakan sebuah algoritma optimasi stokastik. Sejak pertama kali ditemukan, algoritma PSO telah digunakan secara luas untuk memecahkan masalah optimasi (Niknam dan Amiri, 2010: 184). Model matematika untuk PSO dapat dilihat pada persamaan 11.

$$
\begin{array}{r}
V i^{(t+1)}=\omega \cdot V i^{(t)}+c 1 \cdot \operatorname{ramd}_{1}(.) \cdot\left(P_{\text {best } i}-X i^{(t)}\right)+c 2 \cdot \operatorname{rand}_{2}(.) \cdot\left(G_{\text {best }}\right. \\
\left.\left.-X i^{(t)}\right) X i^{(t-1)}\right)=X i^{(t)}+-V i^{(t+1)} ; i=1,2,3, \ldots \text { Nswarm }
\end{array}
$$

Keterangan: $\mathrm{i}=$ Indeks dari setiap partikel, $\mathrm{t}=\mathrm{Jumlah}$ iterasi atau pengulangan, $\operatorname{rand}_{1}($.$) dan$ $\operatorname{rand}_{2}()=$. Nomor acak antara 0 dan $1, \mathrm{P}_{\text {besti }}=$ Pengalaman terbaik dari partikel ke-I yang tercatat, $\mathrm{G}_{\text {best }}=$ Partikel terbaik di antara seluruh populasi, Nswarm $=$ Jumlah kawanan, Konstanta $\mathrm{c}_{1}$ dan $\mathrm{c}_{2}=$ Faktor bobot dari istilah percepatan stokastik yang menarik setiap partikel terhadap posisi $\mathrm{P}_{\text {besti }}$ dan $\mathrm{G}_{\text {best }}, \mathrm{t}_{\max }=$ Jumlah maksimum iterasi atau pengulangan, $\omega=$ Berat inersia, $\omega_{\max }=$ Berat inersia maksimum, $\omega_{\min }=$ Berat inersia minimum, $\mathrm{K}=$ Jumlah variabel.

Sebagaimana ditunjukkan dalam Persamaan 11, terdapat tiga parameter penyetelan (tuning parameter), yaitu $\omega, \mathrm{c}_{1}$, dan $\mathrm{c}_{2}$ yang masing-masing memilikidampak yang besar pada kinerja algoritma. Berat inersia mengontrol sifat eksplorasi algoritma. Learning factor $\mathrm{c}_{1}$ dan $\mathrm{c}_{2}$ masing-masing menentukan dampak dari $P_{\text {besti }}$ terbaik dan $G_{\text {best }}$ terbaik. Jikac $1>\mathrm{c}_{2}$, maka partikel memiliki kecenderungan untuk berkumpul ke posisi terbaik yang ditentukan oleh dirinya sendiri $\left(P_{\text {best }}\right)$ dibandingkan posisi terbaik yang ditemukan oleh populasi $\left(G_{b e s t}\right)$, dan sebaliknya. Kebanyakan implementasi menggunakan pengaturan dengan $\mathrm{c}_{1}=\mathrm{c}_{2}=2$.

\subsection{Eksperimen dan Evaluasi}

Eksperimen dilakukan sebagai uji coba pada penelitian ini dan evaluasi dilakukan sebagai pengukuran keberhasilan dalam penelitian ini.

\subsubsection{Eksperimen}

Pada bagian ini, kami menerapkan pendekatan yang diusulkan untuk pengelompokan audio. Pertama-tama, kita harus membangun sebuah audio library yang terdiri dari musik pop, musik dangdut, dan musik rock. Data audio yang digunakan dalam percobaan adalah stereo, encoding dari 64 bit, dan sampling rate $44100 \mathrm{~Hz}$. Dalam proses penelitian, kami secara acak memilih 68 fragmen masing-masing kelas sebagai set pelatihan, dan sisanya digunakan sebagai set tes.

\subsubsection{Evaluasi}

Evaluasi klaster digunakan untuk mengetahui klaster yang akurat dengan menggunakan cohesion, separation dan pengukuran menggunakan F-Measure.

\subsubsection{Cohesion dan Separation}

$K$-means merupakan algoritma clustering yang bersifat partitional yaitu membagi himpunan objek data ke dalam sub himpunan (cluster) yang tidak overlap, sehingga setiap objek data berada tepat dalam satu cluster. Strategi partitional-clustering yang paling sering digunakan adalah berdasarkan kriteria square error. Secara umum, tujuan kriteria square error adalah untuk memperoleh partisi (jumlah cluster tetap) yang meminimalkan total square error (Tan, 2007:496).

SSE (Sum Squared of Error) menyatakan total kesalahan kuadrat yang terjadi bila $n$ data inx $, \ldots, x$ dikelompokkan ke dalam $k$ cluster dengan pusat tiap cluster adalah $k m, \ldots, m 1$. Nilai SSE tergantung pada jumlah cluster dan bagaimana data dikelompokkan ke dalam clustercluster tersebut. Semakin kecil nilai SSE, semakin bagus hasil clustering-nya (Tan, 2007: 539). 
Adapun rumus SSE dapat dilihat pada Persamaan 12.

$\mathrm{SSE}=\sum_{I=0}^{K} \sum_{\mathrm{x} \in \mathrm{Ci}}\|\mathrm{x}-\mathrm{mi}\|$

Keterangan: $\mathrm{k}=$ Jumlah Klaster, $\mathrm{C}_{\mathrm{i}}=$ Set Data $\mathrm{C}$ ke-i, $\mathrm{x}=$ Nilai set Data, $\mathrm{m}_{\mathrm{i}}=$ Mean (rata-rata) dari setiap klaster.

Besaran separation antar klaster adalah SSB (Sum of Square Between-group), jumlah kuadrat jarak dari sebuah klaster centroid mi terhadap setiap cluster centroid lainnya $x$. Dengan menjumlahkan SSB dari setiap klaster, diperoleh total SSB (Persamaan 13) (Tan, 2007:540).

$\mathrm{SSB}=\sum_{I=0}^{K} \sum_{\mathrm{x} \in \mathrm{Ci}} \mathrm{ni}\|\mathrm{x}-\mathrm{mi}\|$

Keterangan: $\mathrm{k}=$ Jumlah klaster, $\mathrm{ni}=$ Ukuran sampel dari data ke-I, $\mathrm{x}=$ Nilai set data, $\mathrm{m}_{\mathrm{i}}=$ Mean (rata-rata) dari setiap klaster.

Semakin tinggi nilai total SSB maka semakin jauh jarak suatu cluster terhadap cluster yang lainnya. Dalam beberapa kasus, terdapat relasi yang kuat antara cohesion dan separation. Secara spesifik, jumlah dari total SSE dan total SSB adalah konstan yaitu sama dengan total sum of squares (TSS) (Persamaan 14) sehingga meminimalkan SSE ekuivalen dengan memaksimalkan SSB (Tan, 2007:540).

$T S S=S S E+S S B$

\subsubsection{F-Measure}

F-Measure adalah nilai yang didapatkan dari pengukuran precision dan recall antara kelas hasil cluster dengan kelas sebenarnya yang terdapat pada data masukan (Liu, 2007:73-74). Tabel 1 adalah tabel kebenaran dari kondisi aktual terhadap classified.

Tabel 1. Tabel Kebenaran Kondisi Actual Terhadap Classified

Actual Positive

Actual Negative

\begin{tabular}{|c|c|}
\multicolumn{1}{c}{ Classified Positive } & Classified Negative \\
\hline TP & FN \\
\hline FP & TN \\
\hline
\end{tabular}

Keterangan:

TP : Jumlah klasifikasi yang benar dari contoh positif (true positive).

FN : Jumlah okeklasifikasi yang salah contoh positif (false negative).

FP : Jumlah klasifikasi yang salah contoh negatif (false positive).

$\mathrm{TN}$ : Jumlah klasifikasi yang benar dari contoh negatif (true negative).

Precision dan Recall bisa didapatkan dengan Persamaan 15. Berdasarkan confusion matrix, Precision (p): jumlah sampel berkategori positif diklasifikasi benar dibagi dengan total sampel yang diklasifikasi sebagai sample positif. Recall (r): jumlah sampel diklasifikasi positif dibagi total sampel dalam testing set berkategori positif. F-Measure (F1) adalah harmonic mean dari precision dan recall (Persamaan 16). Semakin besar nilai F-Measure semakin baik kualitas cluster tersebut.

$p=\frac{T P}{T P+F P}, \quad r=\frac{T P}{T P+F N}$ 
$F 1=2 \cdot \frac{\text { Precision } \cdot \text { Recall }}{\text { Precision }+ \text { Recall }}$

\section{Metodologi}

Proses klasterisasi jenis musik pada penelitian ini memiliki beberapa tahap yang harus dilakukan, seperti ditunjukkan pada Gambar 2. Tahap pertama yaitu dilakukan praposes dengan menggunakan preemphasis dan deteksi endpoint. Tahap kedua dilakukan pemrosesan sinyal audio dengan menggunakan metode MFCC. Tahap ketiga dilakukan ekstraksi fitur menggunakan ZCR. Tahap keempat dilakukan pemilihan fitur terbaik dengan menggunakan algoritma NN. Setelah mendapatkan fitur terbaik, dilakukan klasterisasi menggunakan algoritma $K$-means dan dioptimalisasi menggunakan PSO. Setelah itu dilakukan labelisasi untuk mengetahui jenis musik dari setiap file audio.

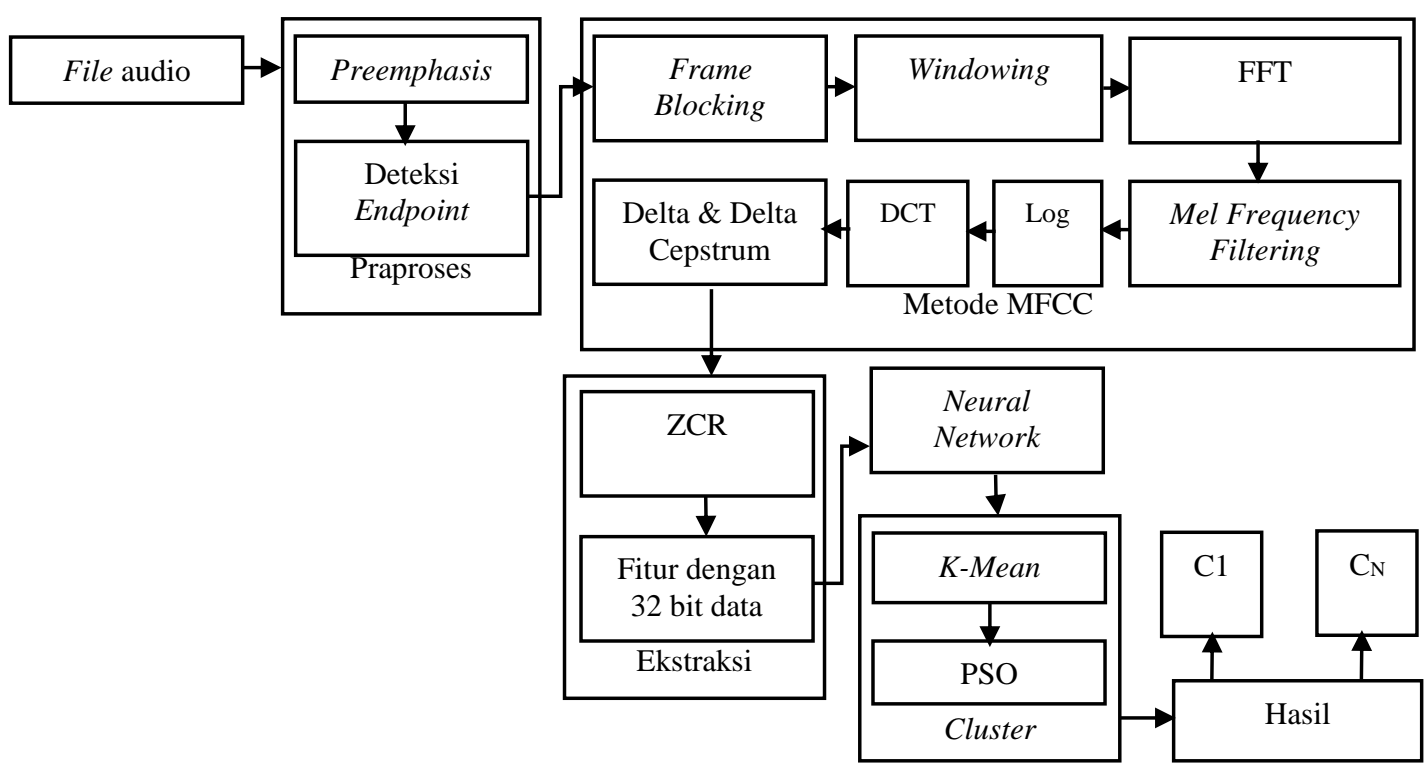

Gambar 2. Desain Sistem Kluster Dokumen Musik

\section{Hasil dan Pembahasan}

Pada tahap praproses, pemrosesan sinyal audio, dan ekstraksi fitur pada penelitian ini ditunjukkan pada ilustrasi Gambar 3. Sinyal audio akan di-capture menggunakan audio streamreader dari aplikasi yang dikembangkan pada penelitian ini seperti ditunjukkan pada Gambar 3(a). Setelah itu sinyal audio akan dilakukan sampling dalam jarak dan durasi satu menit seperti ditunjukkan pada Gambar 3(b). Setelah itu, dengan memanfaatkan metode MFCC dilakukan pemrosesan sinyal audio berupa filtering dan penguatan spektrum sinyal audio seperti ditunjukkan pada Gambar 4(a) dan Gambar 4(b). Setelah itu, dilakukan ekstraksi fitur dengan memanfaatkan ZCR sehingga panjang fitur menjadi 32 bit data, seperti ditunjukkan pada Gambar 5.

(a)
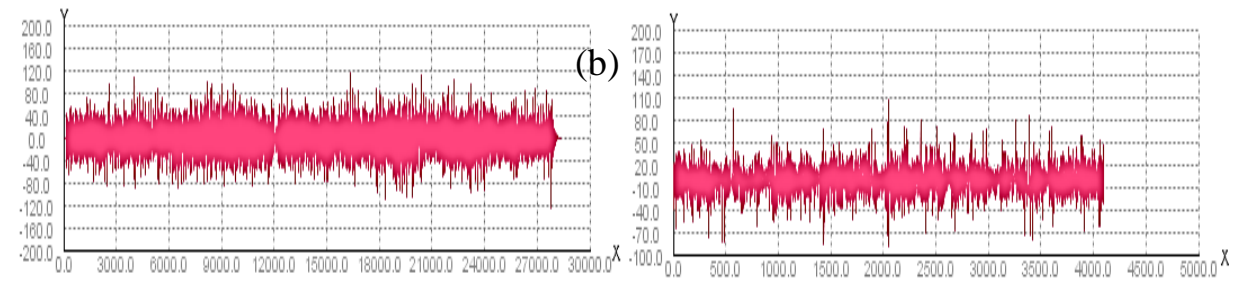

Gambar 3 (a) Sinyal Audio yang Dibaca (b) Sampling Sinyal Audio Dalam Jarak dan Durasi 1 Menit

(Sumber: Grafik aplikasi pada penelitian ini) 
(a)
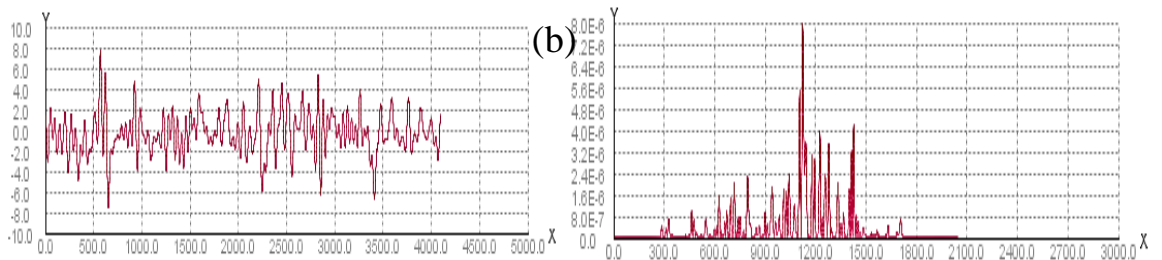

Gambar 4 (a) Sinyal Sampling Audio yang Telah Di-filter (b) Penguatan Spektrum Sinyal Audio (Sumber: Grafik aplikasi pada penelitian ini)

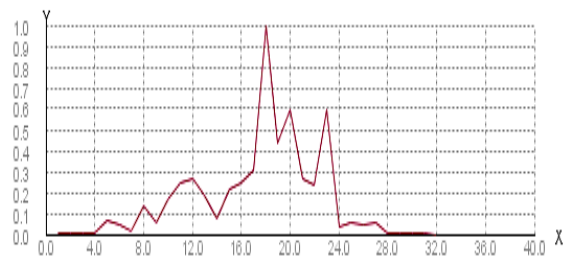

Gambar 5. Fitur Audio yang Dihasilkan, Dengan Panjang Fitur 32 Bit Data. (Sumber: Grafik aplikasi pada penelitian ini)

Berdasarkan analisa spektrum melodi dan bass dari jenis musik, diperoleh fitur-fitur yang dominan dari musik tersebut. Fitur-fitur yang dominan dari musik pop, rock, dan dangdut ditunjukkan pada Gambar 6, Gambar 7, dan Gambar 8.
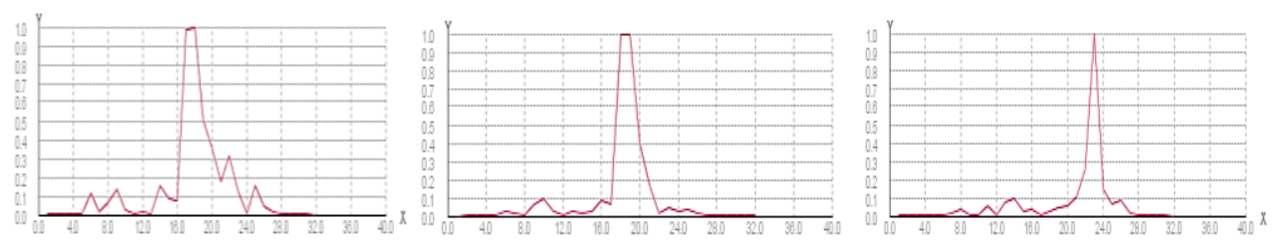

Gambar 6. Karakteristik Fitur Musik Jenis Pop

(Sumber: Grafik aplikasi pada penelitian ini)
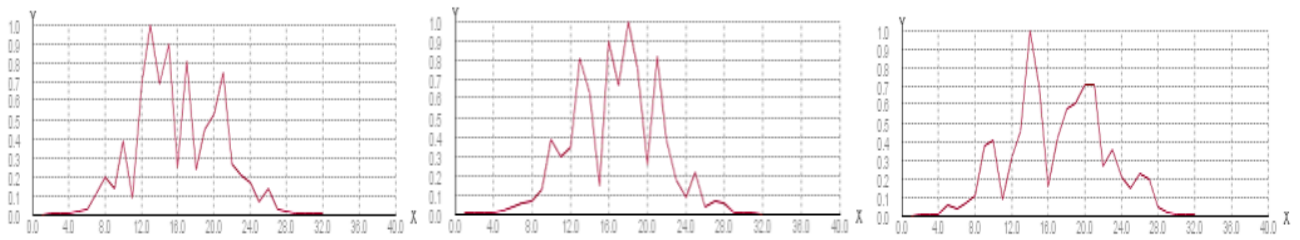

Gambar 7. Karakteristik Fitur Musik Jenis Rock

(Sumber: Grafik aplikasi pada penelitian ini)
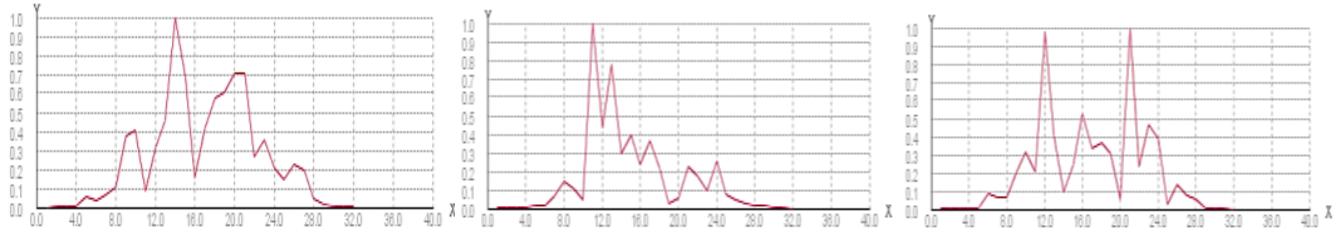

Gambar 8. Karakteristik Fitur Musik Jenis Dangdut (Sumber: Grafik aplikasi pada penelitian ini)

Fitur musik jenis pop memiliki karakteristik dengan spektrum yang berbentuk satu puncak yang tinggi dan puncak lain yang tidak dominan. Fitur musik jenis rock memiliki spektrum yang terdiri dari beberapa puncak yang tinggi. Fitur dangdut memiliki fitur yang hampir sama dengan fitur pop, namun memiliki rata-rata spektrum yang lebih rendah dari rock. Berdasarkan fitur yang diperoleh dari setiap file audio, selanjutnya akan dilakukan pemrosesan menggunakan algoritma NN. Fitur-fitur tersebut akan digunakan sebagai masukan NN. 
Arsitektur NN yang digunakan terdiri dari 32 titik masukan, 64 titik hidden, dua titik keluaran, dan tiga target keluaran. Pemilihan data untuk training NN dilakukan dengan melihat kemiripan terhadap karakteristik bentuk spektrum. Kemiripan tersebut dapat dicari dengan memanfaatkan prosentase error antara target keluaran dengan hasil keluaran. Nilai error dari suatu fitur yang melebihi $20 \%$ tidak digunakan sebagai data training. Fitur yang sangat berbeda dari karakteristik musik tidak digunakan pada proses training agar tidak merusak data serta sebagai alasan untuk mempercepat proses komputasi.

Algoritma NN yang digunakan pada penelitian ini yaitu menggunakan algoritma backpropagation, dikarenakan terdapat fase backward training dan memiliki hasil yang akurat. Pada tahap pengujian, data yang digunakan berupa file audio secara acak pada suatu direktori. Data tersebut akan digunakan sebagai masukan NN sehingga akan dihasilkan keluaran seperti ditunjukkan pada Gambar 9(a). Setelah itu, dilakukan klasterisasi dengan memanfaatkan algoritma $K$-means seperti ditunjukkan pada Gambar 9(b).

Hasil klasterisasi antara Gambar 9(b) dan Gambar 10 memiliki perbedaan. Pada hasil klasterisasi menggunakan algoritma $K$-means clustering memiliki kelemahan, yaitu keakuratan yang tidak terjamin seperti terdapat suatu anggota dari suatu cluster yang tidak masuk ke dalam cluster yang seharusnya walaupun memiliki jarak yang dekat. Dengan menggunakan algoritma PSO, hasil klasterisasi dioptimalisasi sehingga anggota cluster tersebut masuk ke dalam cluster yang seharusnya. PSO memanfaatkan masukan dari hasil akhir nilai centroid $K$-means pada proses sebelumnya. PSO memiliki algoritma yang hampir samadengan $K$-means, khususnya pada tahap mencari nilai SSE. Namun pada tahap update nilai centroid memiliki perbedaan, pada PSO hal tersebut memanfaatkan nilai kecepatan (velocity) dari partikel yang telah dibangun. Algoritma PSO akan mencari nilai global optimum dari setiap centroid sehingga diperoleh hasil klasterisasi yang lebih optimal.

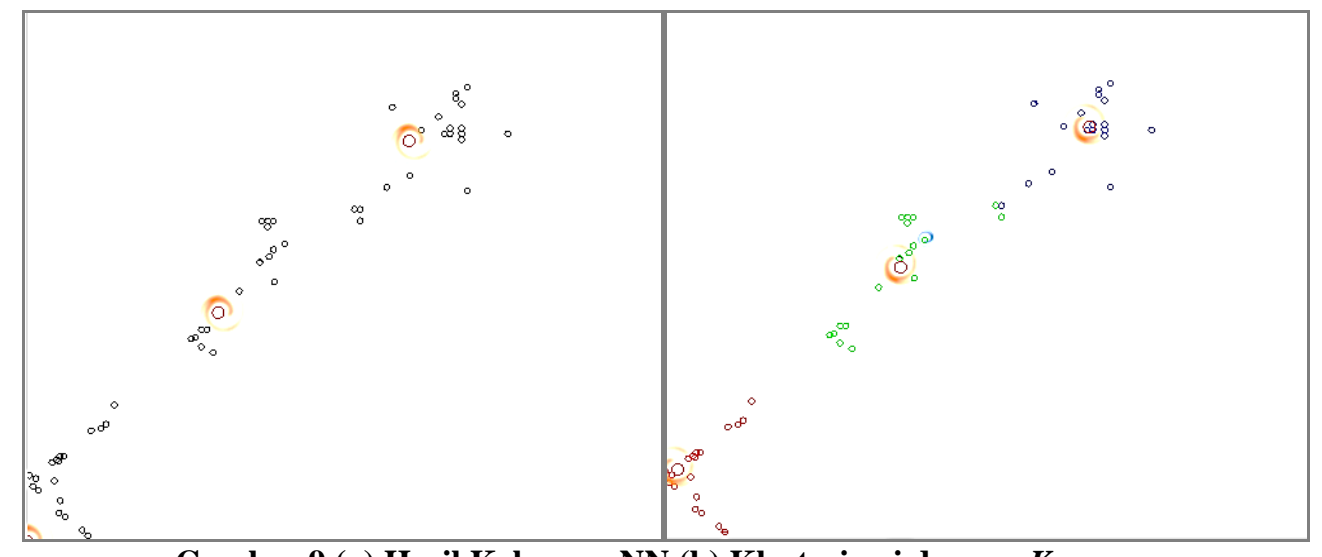

Gambar 9 (a) Hasil Keluaran NN (b) Klasterisasi dengan K-means (Sumber: Grafik aplikasi pada penelitian ini) 


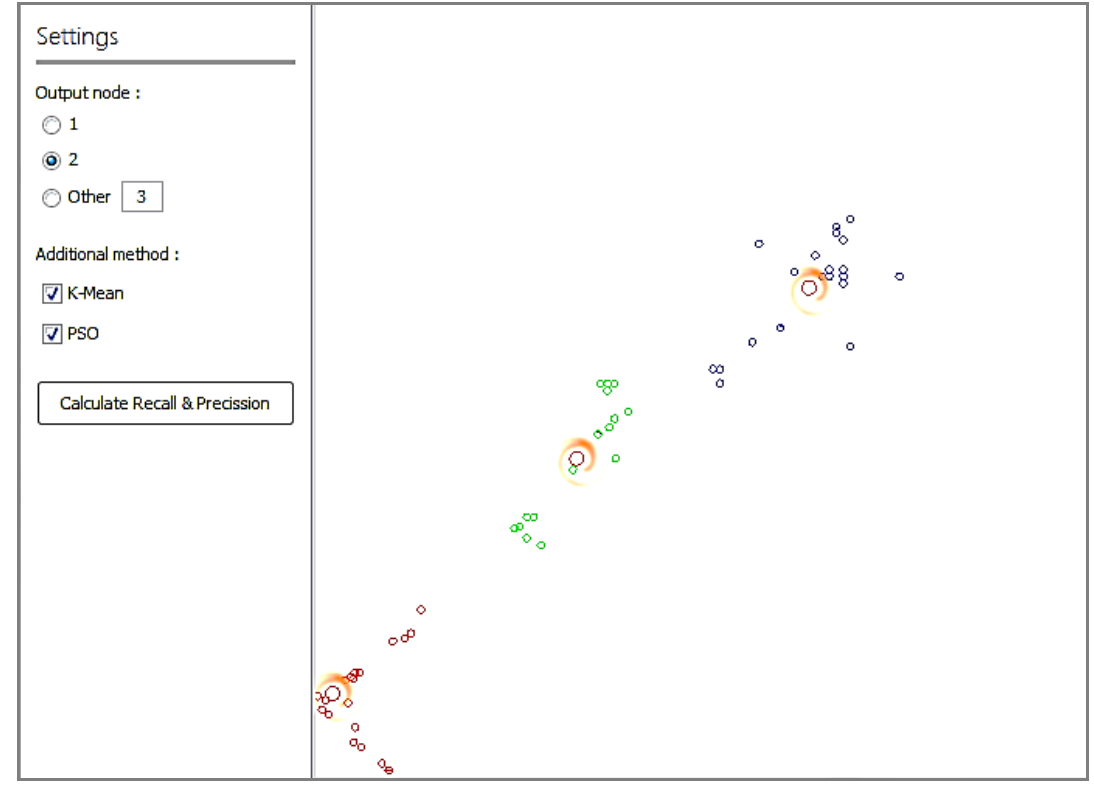

Gambar 10. Optimalisasi Hasil K-means menggunakan PSO (Sumber: Grafik aplikasi pada penelitian ini)

Tabel 2 menunjukkan perbedaan terhadap hasil klasterisasi musik pada file audio dengan menggunakan beberapa pendekatan metode. Data tes yang digunakan pada pengujian tersebut yaitu sebanyak 30 file audio pada suatu direktori. Semakin banyak data tes, semakin terlihat perbedaan hasil klasterisasi yang dihasilkan.

Tabel 2. Perbedaan Hasil Klusterisasi

\begin{tabular}{lcccccc}
\hline \multicolumn{1}{c}{ Metode } & Presisi (\%) & Recall $(\boldsymbol{\%})$ & SSE & SSB & TSS & F-Measure (\%) \\
\hline NN & 75 & 100 & 5.51232 & 5.862951 & 11.37527 & 85.71 \\
\hline NN+K-means & 90 & 100 & 5.51232 & 5.86295 & 11.3752 & 94.73 \\
\hline NN+K-means+PSO & $\mathbf{9 5}$ & 100 & 6.531133 & 6.351476 & 12.88261 & $\mathbf{9 7 . 4 4}$ \\
\hline
\end{tabular}

Tabel 3 menunjukkan hasil pengujian kombinasi metode NN, K-means, dan PSO pada parameter cohesion, separation, dan F-Measure dengan jumlah klaster yang sama yaitu tiga, yang mempunyai arti bahwa setiap satu parameter kelompok mendapatkan label jenis musik. Hasil uji coba menunjukkan bahwa presisi terbaik di lakukan dengan dataset sebanyak 20 yaitu 95\% dan untuk recall setiap uji coba hasilnya sama yaitu $100 \%$ dan F-Measure terbaik ditemukan di penggunaan dataset sebanyak 20 yaitu 97,44\%.

Tabel 3. Nilai Rata-rata Hasil Uji Coba

\begin{tabular}{cccccccc}
\hline Percobaan & $\begin{array}{c}\text { Jumlah } \\
\text { Dataset }\end{array}$ & Presisi (\%) & Recall $(\boldsymbol{\%})$ & SSE & SSB & TSS & F-Measure $(\boldsymbol{\%})$ \\
\hline $\mathbf{1}$ & $\mathbf{1 0}$ & 90.00 & 100 & 3.046219 & 2.576869 & 5.618906 & 94.74 \\
\hline $\mathbf{2}$ & $\mathbf{1 2}$ & 91.67 & 100 & 4.117232 & 2.393627 & 7.053504 & 95.65 \\
\hline $\mathbf{3}$ & $\mathbf{1 4}$ & 92.86 & 100 & 4.900875 & 3.675933 & 8.576809 & 96.30 \\
\hline $\mathbf{4}$ & $\mathbf{1 6}$ & 93.75 & 100 & 5.193481 & 4.394548 & 9.58803 & 96.77 \\
\hline $\mathbf{5}$ & $\mathbf{1 8}$ & 94.44 & 100 & 5.3586 & 5.298674 & 10.65727 & 97.14 \\
\hline $\mathbf{6}$ & $\mathbf{2 0}$ & $\mathbf{9 5 . 0 0}$ & 100 & 6.531133 & 6.351476 & 12.88261 & $\mathbf{9 7 . 4 4}$ \\
\hline $\mathbf{7}$ & $\mathbf{2 2}$ & 90.91 & 100 & 6.577217 & 7.096729 & 13.67395 & 95.24 \\
\hline $\mathbf{8}$ & $\mathbf{2 4}$ & 91.67 & 100 & 7.129259 & 7.613228 & 14.74249 & 95.65 \\
\hline $\mathbf{9}$ & $\mathbf{2 6}$ & 88.46 & 100 & 7.725598 & 8.193825 & 15.91942 & 93.88 \\
\hline $\mathbf{1 0}$ & $\mathbf{2 8}$ & 89.29 & 100 & 7.789668 & 8.983771 & 16.77344 & 94.34 \\
\hline $\mathbf{1 1}$ & $\mathbf{3 0}$ & 90.00 & 100 & 7.856915 & 9.891201 & 17.74812 & 94.74 \\
\hline
\end{tabular}

Nilai yang diperoleh tersebut juga dipengaruhi oleh penentuan threshold pada NN untuk seleksi fitur pada proses training. Semakin kecil prosentase threshold error yang digunakan, maka semakin akurat keluaran yang dihasilkan. 


\section{Kesimpulan dan Saran}

Metode yang peneliti usulkan dalammelakukan klasterisasi data musik dengan jumlah klaster yang optimal yaitu dengan menggunakan kombinasi algoritma NN, K-means, dan PSO. Hasil penelitian ini diharapkandapat melakukan klasterisasi berbagai macam jenis musik dengan baik, khususnya dalam mendapatkan kelas yang sesuai dengan fitur yang dimilikinya. Hasil akhir penelitian ini memiliki nilai presisi $95 \%$, recall setiap uji coba hasilnya sama yaitu 100\%, dan F-Measure terbaik ditemukan di penggunaan dataset sebanyak 20 yaitu 97,44\%.

Penelitian kedepannya akan menggunakan berbagai macam format file audio, tidak terbatas pada file audio dengan format MP3. Selain itu, juga akan dilakukan penelitian dengan menggunakan pendekatan lain di samping menggunakan pendekatan analisa terhadap spectrum melodi dan bass pada tahap pemrosesan sinyal dan ekstraksi fitur.

\section{Referensi}

Gupta, S., Jaafar, J., Ahmad, W.F., dan Bansal, A. 2013. Feature Extraction Using MFCC.Signal \& Image Processing: An International Journal (SIPIJ), Vol. 4, No. 4:101-108.

Jaganathan, P., and Jaiganesh, S. 2013. An improved K-means algorithm combined with Particle Swarm Optimization approach for efficient web document clustering. IEEE. 978-1-4673-6126-2/13: 772-776.

Keerio, A., Mitra, B.K., Birch, P., Young, R., dan Chatwin, C. 2013. On Preprocessing of speech signal.International Journal of Signal Processing, Vol. 5, No.3: 216-222.

Li, Tao. and S. Zhu. 2009. Music Clustering With Features From Different Information Sources. IEEE Transactions on Multimedia. VOL. 11, NO. 3, April 2009: 477-485.

Liu, Bing. 2007. Web Data Mining. Chicago: ACM Computing Classification.

Meyers, C.O. 2004. AMood-Based Music Classification and Exploration System. McGill University: Program in Media Arts and Sciences.

Niknam, T., and Amiri, B. 2010. An Efficient Hybrid Approach Based on PSO, ACO And KMeans for Cluster Analysis. Applied Soft Computing, 10 (2010): 183-197.

Oxford University Press. 2014. Definition of music in English. (http://oxforddictionaries.com/definition/english/music, diakses 1 Desember 2015).

Saputra, Wahyu S. J, Sujatmika Arif Rahman, Arifin Agus Zainal.2011. Seleksi Fitur Menggunakan Random Forest Dan Neural Network. Industrial Electronics Seminar: 93-97.

Suhartono. 2007. Feedforward Neural Network Untuk Pemodelan Runtun Waktu. Distertasi. Yogyakarta: Universitas Gadjah Mada.

Tan, P-N., Steinbach, M., Kumar, V. 2007. Cluster Analysis: Basic Concepts and Algorithms. In: Introduction to Data Mining. Boston: Pearson Addison Wesley. P.

Wang, Yunhui, Yu Xiaoqing. 2011. The research of audio clustering with Gaussian mixture based on em algorithm. CCWMC: 389-393.

Yang, Y.H, Liu, C.C., and Chen, H.H. 2009. Clustering For Music Search Result. Taipei: National Taiwan University. 